\title{
Dental Protraction
}

National Cancer Institute

\section{Source}

National Cancer Institute. Dental Protraction. NCI Thesaurus. Code C82128.

Anterior displacement of the teeth and/or bones of the face. 